\title{
STUDY OF PALMAR DERMATOGLYPHICS PATTERN CHANGES IN $\beta$-THALASSEMIA MAJOR PATIENTS
}

\author{
Debjyoti Basu11, Bhaskar Pal2, Premananda Bharati ${ }^{3}$
}

${ }^{1}$ Assistant Professor, Department of Anatomy, College of Medicine \& Sagore Dutta Hospital, Kamarhati, Kolkata.

2 Professor, Department of Anatomy, R. G. Kar Medical College, Kolkata.

3 Professor, Department of Biological Anthropology Unit, Indian Statistical Institute, Kolkata.

\begin{tabular}{l} 
ABSTRACT \\
\hline Palmar dermatoglyphics pattern in $\beta$-Thalassemia major patients and in normal subjects were studied to find out any \\
statistically significant changes if present.
\end{tabular}

statistically significant changes if present.

\section{SETTING AND DESIGN}

Qualitative and quantitative changes in the pattern may be present, as these patterns are genetically determined.

\section{BACKGROUND}

$\beta$-Thalassemia major is a serious and prevalent form of haemoglobin disorder in these regions with autosomal recessive pattern of inheritance. Study of population by applying different tools is an important aspect of prevention. Dermatoglyphics study may be helpful to know the phenotypic trait of the individual.

\section{METHODS AND MATERIALS}

50 diagnosed cases of $\beta$-thalassemia major and the equal number of matched control group of either sex were included in the investigation. Palmar imprints were taken by traditional paper and ink method.

\section{STATISTICAL ANALYSIS}

Chi square test and t- test were used.

\section{RESULTS AND CONCLUSION}

Arch, loop and whorl's character, a-b ridge counts and 'atd' angles were studied. Significant rise in number of whorls and changes in 'atd' angles were detected in the cases. This information may be useful in population genetics study, though more detail research is needed.

\section{KEYWORDS}

Dermatoglyphics, Palmar, $\beta$-Thalassemia.

HOW TO CITE THIS ARTICLE: Basu D, Pal B, Bharati P. Study of palmar dermatoglyphics pattern changes in $\beta$-thalassemia major patients. J. Evolution Med. Dent. Sci. 2016;5(33):1805-1808, DOI: 10.14260/jemds/2016/425

\section{INTRODUCTION}

Epidermis of palms and soles has a characteristic pattern of epidermal ridges appeared during intrauterine life. Apart from some other factors, heredity plays an important role in development of these ridges. Dermatoglyphics is a scientific study of epidermal ridges of palms and soles. Such studies started back in 1926.[1] Because of its unique nature, the dermatoglyphic studies are increasingly drawing attention in anthropological survey, population genetics. In medical practice it can be an alternative tool for diagnosing hereditary diseases like diabetes, hypertension, schizophrenia as well as some haemoglobinopathies. Common disorder of haemoglobin synthesis in our country is ß-thalassemia.[2] It is a single gene disorder with autosomal recessive pattern of inheritance. In homozygous state $ß$-thalassemia is the most severe form of the disease with high morbidity and mortality and is classified as ß-thalassemia major.

Financial or Other, Competing Interest: None.

Submission 05-03-2016, Peer Review 01-04-2016,

Acceptance 06-04-2016, Published 23-04-2016.

Corresponding Author:

Dr. Debjyoti Basu,

Village-Haripal, (Royapara),

P.O.+P. S. Haripal Dist.,

Hooghly-712403.

E-mail: debjyotibasuhpl@gmail.com

DOI: $10.14260 /$ jemds $/ 2016 / 425$
It puts immense pressure on the health system of the country, as survival of these patients depends on regular blood transfusion. Objective of this study is to find out whether there are any statistical significant changes in the palmar dermatoglyphics patterns of the $ß$-thalassemia major patients in comparison with normal subjects.

\section{MATERIALS AND METHODS}

Fifty diagnosed ß-thalassemia major patients of either sex attending haematology O.P.D. of Medical College, Kolkata, were selected as cases. Matched control group of same number of healthy volunteers of either sex of $1^{\text {st }}$ year M.B.B.S. class. The data on dermatoglyphics patterns of both palms and fingers were collected by traditional ink and paper method.

\section{Measuring Different Parameter}

Dermatoglyphics is the scientific study of epidermal ridge configurations of fingers, toes, palms and soles. The following characters of the palmar prints were considered for evaluation in the present study. A triradius is the meeting point of three systems of parallel ridges. These epidermal ridges form different patterns like Arch, Loop and Whorl.

1. The Arches may be simple (Fig. 1a), where parallel ridges pass across the finger with slight distal bow and there is no triradius. In tented arch epidermal ridges overtop a triradius (Fig. 1b). 
2. In case of loops (Fig. 2a), the ridges curve around only one extremity of pattern known as head. The opposite extremity is known as 'Open.' There is a single triradius. According to the side of opening of the curve loops may be ulnar loop or radial loop (Fig. 2b).

3. Whorls (Fig. 3) are patterns where ridges curve around 360 degrees with two triradii.

\section{RESULTS}

On the basis of above characters, the following parameters are taken into consideration

1. Arches, loops and whorls of both palms were observed and distribution pattern in control group and $B$ thalassemia major patients were compared (Pattern type).

2. a-b ridge count: Triradius below the $2^{\text {nd }}$ finger is marked. If more than one triradius is present, the nearest point to the radial border was taken into account (a). Triradius below the $3^{\text {rd }}$ digit was marked as (b). They were joined by a fine straight line and the ridges are counted (Fig. 4).

3. 'atd' angle: It was recorded by drawing lines from the digital triradius ' $a$ ' to the axial triradius ' $t$ ' and from this to digital triradius 'd.' The maximal 'atd' angle is an important parameter for this study (Fig. 5).

\section{DISCUSSION}

In this study, statistically significant increase in the whorl pattern was observed which corroborate with findings of Rosner and Spriggs ${ }^{[3]}$ Saha et al[4] observed that in $\beta$ thalassemia, the incidence of whorls is higher with decreased frequency of loops, which is similar to present observations. Dehenkar et al[5] also found statistically significant increase of the whorl pattern in thalassemic patients. However, Bhalla et al[ ${ }^{6]}$ observed an increased incidence of loops, but number of whorls was less.

Rosner and Spriggs ${ }^{[3]}$ found no significant change of $a-b$ ridge count in $\beta$-thalassemia. Similar results were also provided by Saha et al[4], Bhalla et al[6] reported a higher mean a-b ridge count in patients. In this study, the result reflected some decrease in mean $a-b$ ridge count in the imprints of $\beta$-thalassemic palms.

Regarding 'atd' angle, Rosner and Spriggs[3] found no observable differences. This is similar to results of Saha et al[4]. However, Dehenkar et al[5] reported increased 'atd' angles in $\beta$-thalassemic patients than control group. In this study, a significant increase in 'atd' angle in $\beta$-thalassemia cases was observed.

\begin{tabular}{|c|c|c|c|c|c|c|c|}
\hline Subject & $\begin{array}{c}\text { No. of } \\
\text { Individuals }\end{array}$ & Whorl (\%) & Ulnar Loop (\%) & $\begin{array}{c}\text { Radial } \\
\text { Loop (\%) }\end{array}$ & $\begin{array}{l}\text { Arch } \\
(\%)\end{array}$ & $\chi^{2}$ & Remarks \\
\hline Control individuals & 50 & $\begin{array}{c}31.8 \\
(159)\end{array}$ & $\begin{array}{l}59.4 \% \\
(297\end{array}$ & $\begin{array}{l}2.8 \% \\
(14)\end{array}$ & $\begin{array}{l}6.0 \% \\
(30)\end{array}$ & \multirow{3}{*}{8.22} & \multirow{3}{*}{ Significant } \\
\hline \multirow[t]{2}{*}{ Thalassemic patients } & 50 & $\begin{array}{c}38.4 \\
(192)\end{array}$ & $\begin{array}{l}55.2 \% \\
(276)\end{array}$ & $\begin{array}{c}1.0 \% \\
(5)\end{array}$ & $\begin{array}{l}5.4 \% \\
(27)\end{array}$ & & \\
\hline & Whorl = W & Ulnar loop $=\mathrm{L}^{\mathrm{u}}$ & Radial loop $=\mathrm{L}^{\mathrm{r}}$ & $\operatorname{Arch}=\mathrm{A}$ & & & \\
\hline
\end{tabular}

\begin{tabular}{|c|c|c|c|c|c|c|}
\hline Subject & $\begin{array}{c}\text { No. of } \\
\text { Individuals }\end{array}$ & Mean a-b Ridge Count & $\mathbf{\pm S . E .}$ & S.D. & t-value & Remark \\
\hline $\begin{array}{c}\text { Control } \\
\text { Individuals }\end{array}$ & 50 & 77.02 & 1.04 & 7.41 & \multirow{2}{*}{1.06} & Insignificant \\
\hline $\begin{array}{c}\text { Thalassemia } \\
\text { Patients }\end{array}$ & 50 & 75.30 & 1.22 & 8.65 & Table 2: Shows Mean 'a-b' Ridge Count (Sum Both Hands) \\
\hline \multicolumn{7}{|c|}{} \\
\hline
\end{tabular}

\begin{tabular}{|c|c|c|c|c|c|c|}
\hline Subject & $\begin{array}{c}\text { No. of } \\
\text { Individuals }\end{array}$ & $\begin{array}{c}\text { Mean 'atd' } \\
\text { Angle }\end{array}$ & $\mathbf{\pm S . E . ~}$ & S.D. & t-value & Remark \\
\hline $\begin{array}{c}\text { Control } \\
\text { Individuals }\end{array}$ & 49 & 42.22 & 0.76 & 5.38 & & \multirow{2}{*}{ Significant } \\
\hline $\begin{array}{c}\text { Thalassemia } \\
\text { Patients }\end{array}$ & 46 & 44.93 & 1.02 & 6.96 & 2.13 \\
\hline \multicolumn{7}{c}{ Table 3: Shows Mean 'atd' Angle of Left Hands in Both Groups } \\
\hline
\end{tabular}

\begin{tabular}{|c|c|c|c|c|c|c|}
\hline Subject & $\begin{array}{c}\text { No. of } \\
\text { Individuals }\end{array}$ & $\begin{array}{c}\text { Mean 'atd' } \\
\text { Angle }\end{array}$ & $\mathbf{\pm S . E .}$ & S.D. & t-value & Remark \\
\hline $\begin{array}{c}\text { Control } \\
\text { Individuals }\end{array}$ & 49 & 41.69 & 0.66 & 4.63 & 2.17 & Significant \\
\hline $\begin{array}{c}\text { Thalassemia } \\
\text { Patients }\end{array}$ & 46 & 43.95 & 0.81 & 5.50 & \\
\hline \multicolumn{7}{r}{} \\
\hline
\end{tabular}




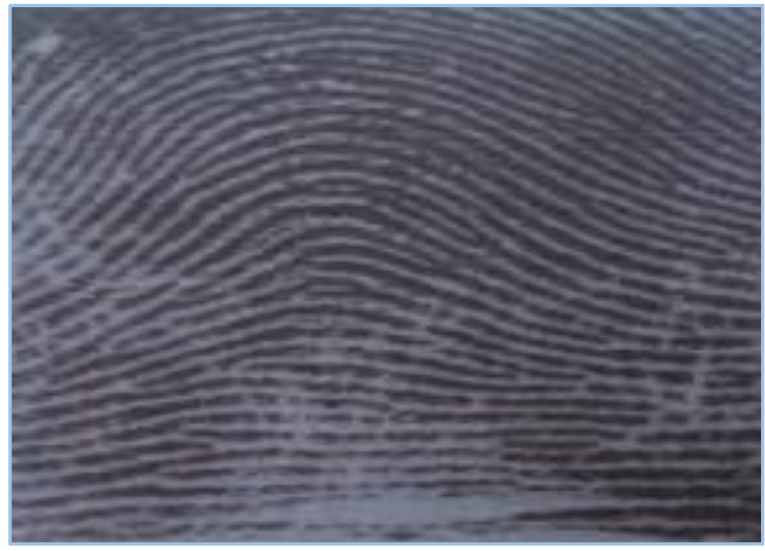

Fig. 1a: The Arches (No Triradius)

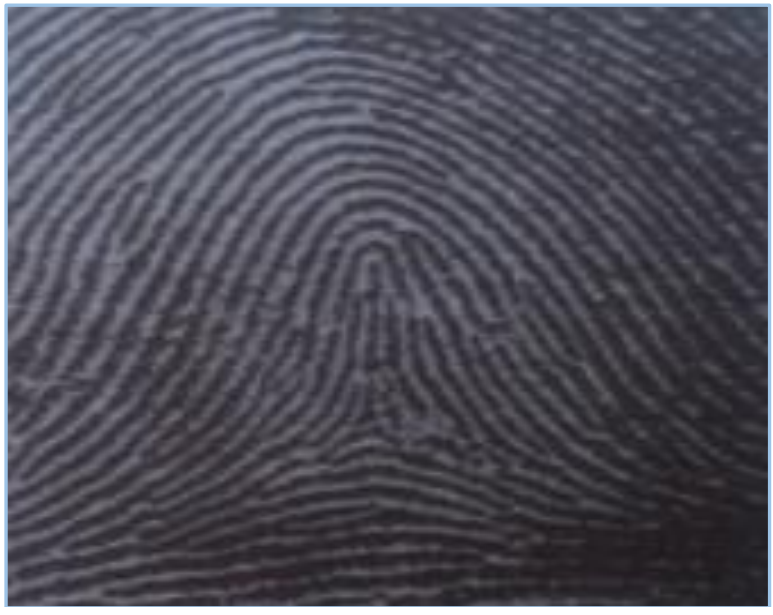

Fig. 1b: Tented Arches (With Triradius)

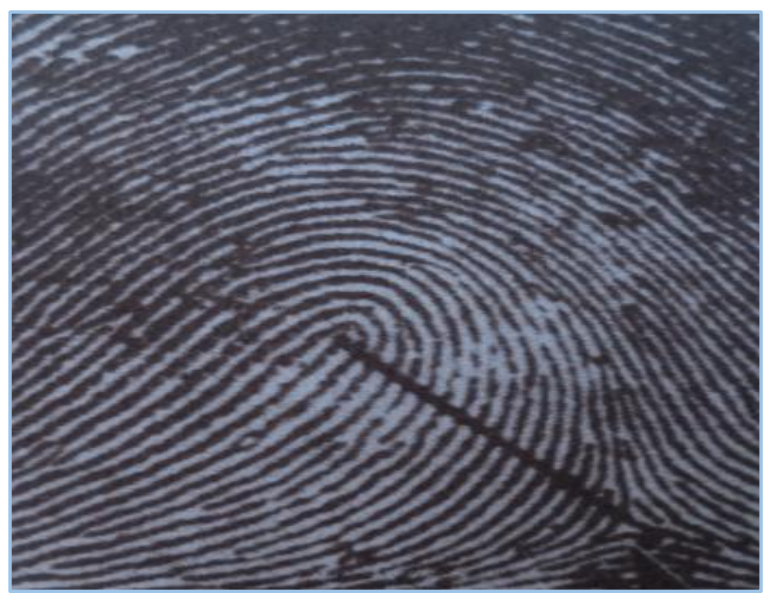

Fig. 2a: The Loops

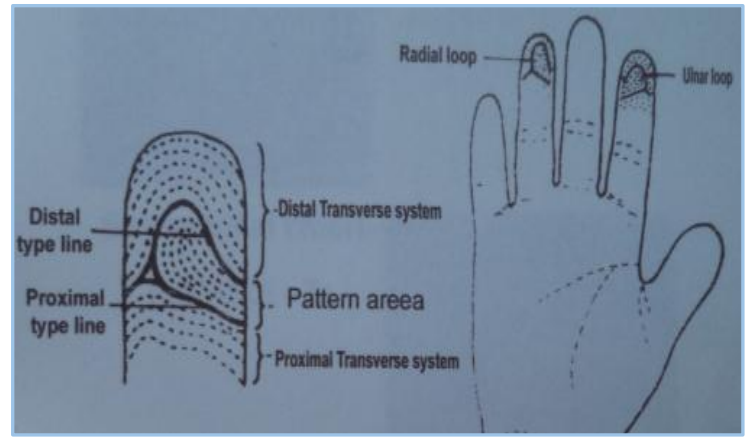

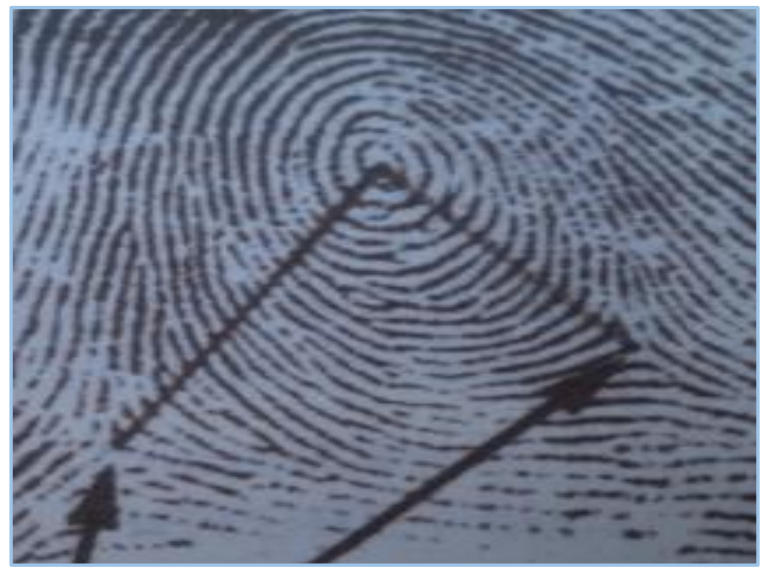

Fig. 3: The Whorl

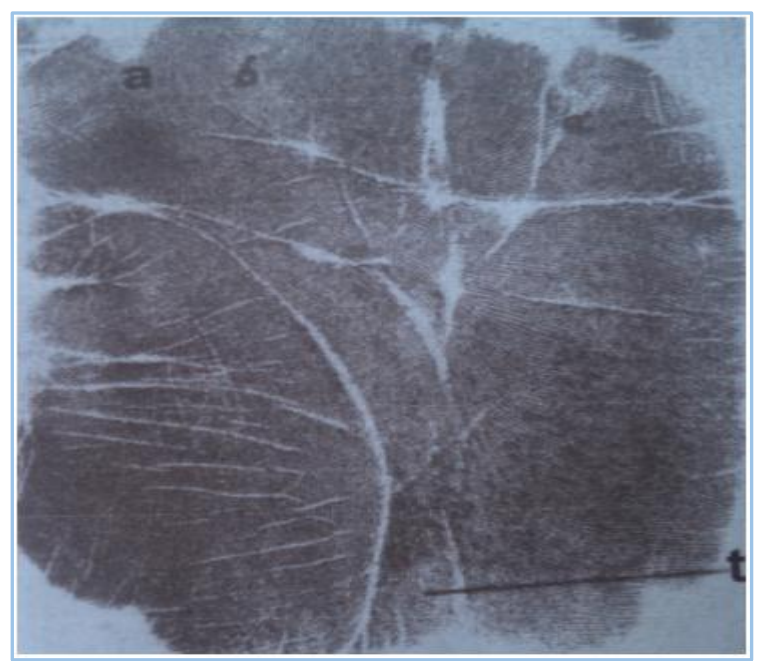

Fig. 4a: Different Triradius

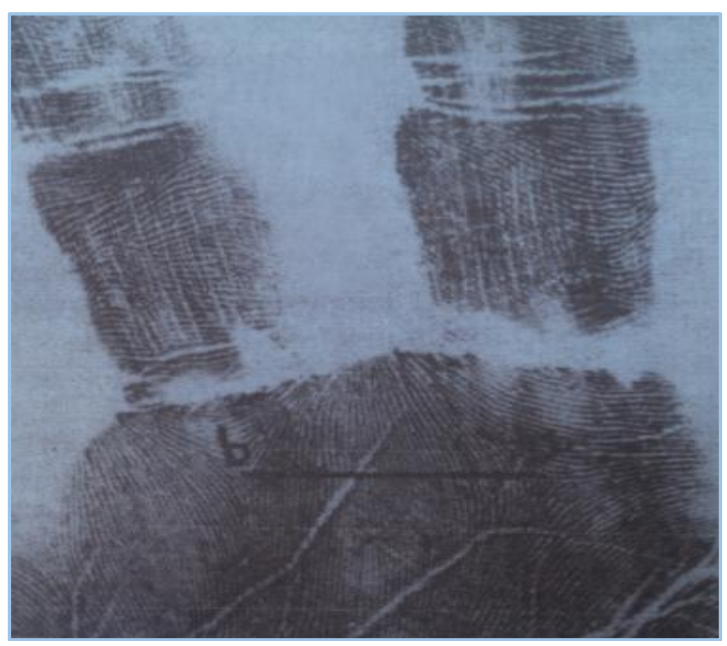

Fig. 4b: Ridges between ' $a$ ' and 'b'

\section{CONCLUSION}

Significant Pattern Changes in the Cases are

1. Increase in whorls in digital imprints.

2. There is statistically significant rise of 'atd' angles in both palms.

Therefore, there are some suggestive changes in dermatoglyphics pattern in palms of $\beta$-thalassemia patients. However, more extensive studies are needed.

Fig. 2b: Showing Ulnar and Radial Loops 


\section{REFERENCES}

1. Susan standring. Gray's anatomy the anatomical basis of clinical practice. Livingstone Churchill 2005;39th edn:174.

2. Ghai. In: Ghai OP, Gupta P, Paul VK, eds. Essential Pediatrics, Delhi 2004.Rosner F, Spriggs HA. Dermatoglyphic studies in patients with Cooley's anaemia. Ann NY Acad Sci 1969;165(1):378-86.

3. Saha KC, Chatterjea JB, Mukherjee DP. Dermatoglyphics in thalassemia syndrome. JIMA 1973;61(5):205-11.
4. Dehankar Rajesh N, Ksheersagar DD. Study of dermatoglyphic patterns in thalassemia. Journal of Anatomical Society of India 2007;56(1):102.

5. Bhalla AK, Marwaha RK, Kaer H, et al. Finger and palmar dermatoglyphics in $B$ - thalassemia patients. Mankind Quarterly Spring 2007;47(3). 